INOBIS: Jurnal Inovasi Bisnis dan Manajemen Indonesia

Volume 2, Nomor 1, Desember 2018

Rusdayanti Asma; Redawati

\title{
Pengaruh Mekanisme GCG, Kebijakan Investasi dan Kebijakan Dividen Terhadap Nilai Perusahaan yang Dimediasi Oleh Kebijakan Pendanaan
}

\author{
Rusdayanti Asma \\ (email: rusdayanti97@yahoo.co.id) \\ Redawati \\ Universitas Lambung Mangkurat
}

\begin{abstract}
Abstrak
Tujuan akhir dari perusahaan adalah meningkatkan kemakmuran pemegang saham yang dapat dilihat dari meningkatnya nilai perusahaan. Penelitian ini bertujuan untuk mengetahui Pengaruh Mekanisme GCG, Kebijakan Investasi dan Kebijakan Dividen terhadap Nilai Perusahaan yang dimediasi oleh Kebijakan Pendanaan perusahaan. Populasi penelitian adalah seluruh perusahaan manufaktur yang terdaftar di Bursa Efek Indonesia tahun 2015. Pemilihan sampel menggunakan metode purposive sampling, diperoleh sampel sebanyak 268 perusahaan. Metode analisis data penelitian ini yaitu analisis SEM-PLS dengan menggunakan alat statistic WrapPLS 5.0. Hasil penelitian pengujian pengaruh langsung meunujukkan bahwa Kebijakan investasi berpengaruh terhadap Kebijakan Pendanaan, sedangkan Mekanisme GCG dan Kebijakan dividen tidak berpengaruh terhadap Kebijakan Pendanaan. Hasil Pengujian juga menunjukkan bahwa Kebijakan investasi, Kebijakan dividend dan Kebijakan Pendanaan berpengaruh terhadap nilai Perusahaan sedangkan Mekanisme GCG tidak berpengaruh terhadap nilai Perusahaan. Hasil pengujian pengaruh tidak langsung menunjukkan bahwa kebijakan pendanaan mampu memediasi hubungan antara Kebijakan Investasi dengan nilai perusahaan, tetapi tidak mampu memediasi hubungan antara Mekanisme GCG dan Kebijakan Dividen dengan nilai Perusahaan.
\end{abstract}

Kata Kunci : Mekanisme GCG, Kebijakan Investasi, Kebijakan Dividen, Kebijakan Pendanaan dan Nilai Perusahaan

\section{Pendahuluan}

Nilai perusahaan merupakan gambaran dari kesejahteraan pemegang saham. Semakin tinggi nilai perusahaan maka dapat menggambarkan bahwa semakin sejahtera pula pemiliknya. Nilai perusahaan yang tinggi merupakan salah satu keinginan terbesar dari pemilik perusahaan, sebab semakin tinggi nilai perusahaan maka semakin makmur juga pemegang saham. Nilai perusahaan yang tinggi mencerminkan kinerja perusahaan saat ini dan juga prospek perusahaan di masa depan. Optimalisasi nilai perusahaan yang merupakan tujuan perusahaan dapat dicapai melalui pelaksanaan fungsi manajemen keuangan, dimana satu keputusan keuangan yang diambil akan mempengaruhi keputusan keuangan lainnya dan berdampak pada nilai perusahaan (Fama dan French, 1998).

Nilai perusahaan sangat dipengaruhi oleh kebijakan-kebijakan yang diambil oleh pemilik perusahaan dan manajemen perusahaan seperti kebijakan pendanaan, kebijakan investasi,kebijakan dividen dan tata kelola perusahaan yang baik. Upaya peningkatan nilai perusahaan bisa jadi mengalami kendala, terutama menyangkut permasalahan keagenan dimana ada konflik kepentingan antara pemilik perusahaan dengan manajemen perusahaan. Konflik kepentingan dalam hal ini disebabkan karena pihak manajer bertindak untuk 
INOBIS: Jurnal Inovasi Bisnis dan Manajemen Indonesia

Volume 2, Nomor 1, Desember 2018

Rusdayanti Asma; Redawati

kepentingan pribadi daripada tujuan perusahaan yang salah satunya meningkatkan kesejahteraan pemegang saham. Menurut Jensen \& Meckling (1976) pengaruh dari konflik antara pemilik (owners) dan manajer ini akan menyebabkan menurunkan nilai perusahaan.

Untuk mengurangi terjadinya konflik keagenan, maka perusahaan perlu menerapkan mekanisme corporate governance dalam sistem pengendalian dan pengelolaan perusahaan. Mekanisme corporate governance sebagai suatu sistem yang mengatur dan mengendalikan perusahaan diharapkan dapat memberikan pengawasan terhadap manajemen dalam mengelola perusahaan sehingga hal tersebut dapat meyakinkan pihak prinsipal bahwa mereka akan memperoleh return atas dana yang diinvestasikan.

Selain mekanisme corporate governance, keputusan keuangan perusahaan juga mempengaruhi nilai perusahaan. Pada dasarnya dalam sebuah perusahaan keputusan keuangan terkait mengenai bagaimana perusahaan mendapatkan dana dan mengelolanya sehingga akan menghasilkan keuntungan bagi pemegang saham. Keputusan keuangan perusahaan umumnya terdiri dari keputusan investasi, keputusan pendanaan dan keputusan dividen. Keputusan pengalokasian modal ke dalam usulan investasi harus dievaluasi dan dihubungkan dengan risiko dan hasil yang diharapkan (Hasnawati, 2005). Bagi beberapa perusahaan, aktivitas investasi merupakan unsur penting dari operasi perusahaan dan penilaian kinerja perusahaan mungkin sebagian besar, atau seluruhnya bergantung pada hasil yang dilaporkan pada bagian ini. Dalam Signaling theory, pengeluaran investasi memberikan sinyal positif mengenai pertumbuhan perusahaan dimasa yang akan datang, sehingga dapat meningkatkan harga saham yang digunakan sebagai indikator nilai perusahaan (Wahyudi dan Pawestri, 2006). Dalam hal ini, perusahaan dihadapkan pada keputusan tentang berapa dana yang harus diinvestasikan pada aktiva lancar dan aktiva tetap serta pos-pos yang terkait dengan aktiva lain-lain perusahaan. Dengan aktiva yang tersedia perusahaan harus dapat menghasilkan laba.

Menurut Myers (1977) IOS merupakan kombinasi antara aktiva yang dimiliki (assets in place) dan pilihan investasi di masa yang akan datang dengan net present value positif. Menurut Kallapur,Lafayette dan Trombley (2001) set kesempatan investasi dari suatu perusahaan mempengaruhi persepsi manajer, pemilik, investor dan kreditur terhadap perusahaan. IOS memberi petunjuk yang lebih luas dimana nilai perusahaan tergantung pada pengeluaran perusahaan di masa yang akan datang. Jadi prospek perusahaan dapat ditaksir dari Investment Opportunity Set (IOS). Perusahaan yang memiliki IOS tinggi merupakan indikasi bahwa perusahaan tersebut berkembang (Chung \& Charoenwong, 2013). Perusahaan yang dinilai memiliki prospek bisnis yang berkembang akan membuat investor yakin bahwa perusahaan mampu meningkatkan kemakmuran pemegang saham sehingga permintaan saham perusahaan akan meningkat.

Selain keputusan investasi, keputusan pembagian dividen merupakan suatu masalah yang sering dihadapi oleh perusahaan. Dividen merupakan alasan bagi investor dalam menanamkan investasinya, dimana dividen merupakan pengembalian yang akan diterimanya atas investasinya dalam perusahaan. Adanya peningkatan dividen seringkali disertai dengan peningkatan harga saham, sedangkan pemotongan dividen biasanya akan mengarah pada penurunan harga saham (Brigham \& Houston, 2006). Perusahaan perlu menerap kan kebijakan dividen yang optimal agar nilai dari perusahaan tidak menurun. Menurut Brigham \& Houston (2006), kebijakan dividen perusahaan yang optimal adalah kebijakan yang menghasilkan keseimbangan antara dividen saat ini dan pertumbuhan di masa depan yang memaksimalkan harga saham.

Keputusan yang menyangkut investasi akan menentukan sumber dan bentuk dana untuk pembiayaannya. Kebijakan Struktur modal merupakan keputusan penggunaan sumber dana utang untuk membiayai operasional perusahaan. Penggunaan utang mempunyai konsekwensi 
INOBIS: Jurnal Inovasi Bisnis dan Manajemen Indonesia

Volume 2, Nomor 1, Desember 2018

Rusdayanti Asma; Redawati

menanggung beban biaya bunga, semakin besar jumlah utang, semakin besar biaya bunga yang harus ditanggung, sehingga dapat meningkatkan risiko kebangkrutan. Di sisi lain, penggunaan utang dapat menghemat pembayaran pajak, karena biaya bunga dapat mengurangi pembayaran pajak (Tax deductable). Oleh karena itu penting bagi perusahaan untuk menentukan proporsi utang dalam pembiayaan perusahaan sehingga membentuk keseimbangan sumber dana utang dengan sumber dana ekuitas.

Penelitian mengenai keterkaitan antara mekanisme corporate governance dan keputusan keuangan terhadap nilai perusahaan pernah dilakukan oleh sejumlah Peneliti dan menghasilkan kesimpulan yang berbeda. Siallagan dan Machfoedz (2006) meneliti mengenai pengaruh antara mekanisme GCG dengan nilai perusahaan. Hasil penelitian memperlihatkan GCG berpengaruh terhadap nilai perusahaan. Selain berdampak terhadap kinerja perusahaan, mekanisme GCG juga mampu meningkatkan kepercayaan publik yang nantinya mempengaruhi nilai perusahaan (Atacik \& Jarvis 2006). Beberapa hasil penelitian yang mendukung pernyataan tersebut ialah Ammann (2010), Fallatah \& Dickins (2012), Hartono (2013); Garay \& Gonzales (2008) bahwa nilai perusahaan dipengaruhi secara positif oleh mekanisme GCG. Dari hasil penelitian Ammann (2010) menyimpulkan bahwa biaya pelaksanaan mekanisme tata kelola perusahaan tampaknya lebih kecil dari manfaat pemantauan, sehingga arus kas yang lebih tinggi yang diperoleh untuk investor dan biaya modal yang lebih rendah untuk perusahaan. Di sisi lain hasil penelitian yang dilakukan oleh Gupta (2009) dan Ratih (2011) menunjukkan bukti empiris yang berbeda. Temuan ini menunjukkan bahwa dalam pasar modal di Kanada, laporan tata kelola perusahaan tidak terkait dengan nilai dari perusahaan, ukuran akuntansi dari kinerja perusahaan dan reaksi pasar terhadap pengungkapan tahunan.

Bukti empiris terkait hubungan Kebijakan Investasi dengan nilai perusahaan dilakukan oleh Saputro (2003), yang menemukan adanya kesesuaian Investment opportunity set berbasis pasar dengan realisasi pertumbuhan. Myers (1977) menyatakan bahwa IOS memberi petunjuk yang lebih luas dimana nilai perusahaan tergantung pada pengeluaran perusahaan di masa yang akan datang. Jadi prospek perusahaan dapat ditaksir dari Investment Opportunity Set (IOS). Hal yang sama juga ditemukan dalam penelitian Rachmawati dan Triatmoko (2007), Shintawati (2011) dan Shanti dan Wulaningrum (2005) yang menemukan bahwa Investment Opportunity Set berpengaruh positif terhadap nilai perusahaan.

Agrawal (1994) meneliti kebijakan dividen terhadap semua ekuitas perusahaan dan temuannya adalah bahwa dividen dapat dipandang sebagai subtitusi dari hutang dalam mengurangi agency cost. Jadi, keputusan investasi berpengaruh terhadap keputusan pendanaan, keputusan pendanaan berpengaruh terhadap kebijakan dividen, dan keputusan investasi berpengaruh terhadap kebijakan dividen. Hal yang berbeda ditemukan dalam penelitian Sukirni (2012) dan Bernandhi \& Muid (2014) yang menyimpulkan bahwa kebijakan dividen tidak berpengaruh terhadap nilai perusahaan.

Bukti empiris hubungan struktur modal dengan nilai perusahaan dilakukan oleh Ross (1977), Masulis (1988), Kayhan dan Titman (2003). Ross (1977) menjelaskan bahwa manajer dan pemegang saham tidak mempunyai akses informasi yang sama terhadap perusahaan, ada informasi tertentu yang hanya diketahui oleh manajer. Dampaknya, ketika manajemen menerbitkan utang baru ditangkap sebagai signal prospek baik perusahaan dimasa mendatang, dasar pemikirannya adalah, manajer hanya akan menerbitkan utang baru bila mereka yakin perusahaan dapat memenuhi kewajibannya, alasan tersebut yang menyebabkan utang berpengaruh positif terhadap nilai perusahaan. Masulis (1988), Kayhan dan Titman (2003) dalam penelitiannya juga menemukan bahwa penggunaan utang dapat meningkatkan nilai perusahaan melalui peningkatan harga saham di pasar, dan sebaliknya pengurangan utang akan menurunkan harga saham. Penelitian ini bertujuan untuk mengetahui pengaruh mekanisme 
INOBIS: Jurnal Inovasi Bisnis dan Manajemen Indonesia

Volume 2, Nomor 1, Desember 2018

Rusdayanti Asma; Redawati

GCG, kebijakan investasi dan kebijakan dividen terhadap nilai perusahaan yang dimesiasi oleh kebijakan pendanaan.

\section{Landasan Teori}

\subsection{Agency Theory}

Agency theory dikembangkan oleh Jensen dan Meckling (1976) memandang bahwa manajemen perusahaan sebagai "agents" bagi para pemegang saham, akan bertindak dengan penuh kesadaran bagi kepentingannya sendiri, bukan sebagai pihak yang arif dan bijaksana serta adil terhadap pemegang saham. Dalam perkembangan selanjutnya, agency theory mendapat respon lebih luas karena dipandang lebih mencerminkan kenyataan yang ada. Berbagai pemikiran mengenai corporate governance berkembang dengan bertumpu pada agency theory di mana pengelolaan dilakukan dengan penuh kepatuhan kepada berbagai peraturan dan ketentuan yang berlaku.

\subsection{Nilai Perusahaan}

Menurut Husnan \& Pudjiastuti (2006) nilai perusahaan merupakan harga yang bersedia dibayar oleh calon pembeli apabila perusahaan tersebut dijual. Nurlela \& Islahuddin (2008) menyatakan nilai perusahaan didefinisikan sebagai nilai pasar karena nilai perusahaan dapat memberikan kemakmuran pemegang saham secara maksimum apabila harga saham perusahaan meningkat. Berdasarkan uraian diatas dapat disimpulkan bahwa nilai perusahaan dapat dilihar dari harga saham sebuah perusahaan, yang berarti semakin tinggi harga saham, semakin tinggi pula nilai perusahaan. Nilai perusahaan yang tinggi mengindikasikan kemakmuran pemegang saham, yang berarti tujuan utama perusahaan didirikan yaitu untuk memakmurkan pemilik (pemegang saham) telah tercapai.

\subsection{Mekanisme GCG terhadap Nilai Perusahaan}

Dalam perspekif teori keagenan, agen yang risk adverse dan yang cenderung mementingkan dirinya sendiri akan mengalokasikan resources (berinvestasi) yang tidak meningkatkan nilai perusahaan. Permasalahan agensi ini akan mengindikasikan bahwa nilai perusahaan akan naik apabila pemilik perusahaan biasa mengendalikan perilaku manajemen agar tidak menghamburkan resources perusahaan, baik dalam bentuk investasi yang tidak layak, maupun dalam bentuk shirking. Corporate governance merupakan suatu sistem yang mengatur dan mengendalikan perusahaan yang diharapkan dapat memberikan dan meningkatkan nilai perusahaan kepada para pemegang saham.

\subsection{Kebijakan Investasi dan Nilai Perusahaan}

Teori sinyal menjelaskan bahwa keputusan investasi yang dilakukan mengandung informasi yang berisi sinyal - sinyal akan prospek perusahaan di masa yang akan datang. Maksimum nilai perusahaan akan diperoleh melalui pemilihan investasi yang memberi net present value positif (Hasnawati, 2005). Nilai perusahaan yang dibentuk melalui indikator nilai pasar saham, sangat dipengaruhi oleh peluang-peluang investasi. Pengeluaran investasi memberikan sinyal positif tentang pertumbuhan perusahaan dimasa yang akan datang, sehingga meningkatkan harga saham sebagai indikator nilai perusahaan (signaling theory). 
INOBIS: Jurnal Inovasi Bisnis dan Manajemen Indonesia

Volume 2, Nomor 1, Desember 2018

Rusdayanti Asma; Redawati

\subsection{Kebijakan Dividen dan Nilai Perusahaan}

Menurut Rosiana, Juliarsa dan Sari (2013), teori sinyal pada dasarnya mendorong perusahaan untuk mengungkapkan informasi kepada pihak eksternal karena terjadi asimetri informasi antara manajemen dengan pihak eksternal. Salah satu informasi yang diuangkapkan oleh perusahaan adalah pembagian dividen. Jika perusahaan tidak membagikan dividen atau membagi dividen dalam jumlah kecil maka hal ini bisa saja ditangkap investor sebagai informasi atau sinyal bahwa perusahaan sedang mengalami kondisi keuangan yang kurang baik. Menurunnya kepercayaan investor, memungkinkan investor akan menjual kembali saham yang dimilikinya sehingga, jika terjadi dalam jumlah besar atau serempak dapat membawa pengaruh pada harga saham perusahaan di pasar (Sumiadji, 2011).

\subsection{Kebijakan Pendanaan dan Nilai Perusahaan}

Kebijakan Struktur modal merupakan keputusan penggunaan sumber dana utang untuk membiayai operasional perusahaan. Oleh karena itu, sangat penting bagi perusahaan untuk menentukan proporsi utang dalam pembiayaan perusahaan sehingga membentuk keseimbangan sumber dana utang dengan sumber dana ekuitas. Disatu sisi, perusahaan akan mencari struktur modal yang optimal yang menghasilkan biaya modal yang paling rendah. Disisi lain informasi yang dimiliki oleh manajer dan pemegang saham tidak sama. Akibatnya, ketika pihak manajemen mengumumkan akan menerbitkan utang baru maka pengumuman tersebut dianggap sebagai signal prospek baik perusahaan dimasa mendatang yang pada akhirnya akan meningkatkan harga saham. Alasannya adalah investor menganggap pihak manajemen tidak akan menerbitkan utang jika mereka tidak yakin untuk dapat memenuhi kebutuhannya dan biasanya biaya modal penerbitan utang lebih murah dibandingkan dengan menerbitkan saham baru.

\subsection{Hipotesis Penelitian}

Adapun hipotesis yang digunakan dalam penelitian ini adalah sebagai berikut:

H1: Mekanisme $G C G\left(X_{1}\right)$ berpengaruh terhadap kebijakan pendanaan $\left(Z_{1}\right)$.

H2: Mekanisme GCG $\left(X_{1}\right)$ berpengaruh terhadap nilai perusahaan $\left(Y_{1}\right)$.

H3: Kebijakan investasi $\left(X_{2}\right)$ berpengaruh terhadap kebijakan pendanaan $\left(Z_{1}\right)$.

H4: Kebijakan investasi $\left(X_{2}\right)$ berpengaruh terhadap nilai perusahaan $\left(Y_{1}\right)$.

H5: Kebijakan dividen $\left(X_{3}\right)$ berpengaruh terhadap kebijakan pendanaan $\left(Z_{1}\right)$.

H6: Kebijakan dividen $\left(X_{3}\right)$ berpengaruh terhadap nilai perusahaan $\left(Y_{1}\right)$.

H7: Kebijakan pendanaan $\left(Z_{1}\right)$ berpengaruh terhadap nilai perusahaan $\left(Y_{1}\right)$.

H8: $G C G\left(X_{1}\right)$ berpengaruh terhadap nilai perusahaan $\left(Y_{1}\right)$ melalui kebijakan pendanaan $\left(Z_{1}\right)$.

H9: Kebijakan investasi $\left(X_{2}\right)$ berpengaruh terhadap nilai perusahaan $\left(Y_{1}\right)$ melalui kebijakan pendanaan $\left(Z_{1}\right)$

H10: Kebijakan dividen $\left(X_{3}\right)$ berpengaruh terhadap nilai perusahaan $\left(Y_{1}\right)$ melalui kebijakan pendanaan $\left(Z_{1}\right)$. 
INOBIS: Jurnal Inovasi Bisnis dan Manajemen Indonesia

Volume 2, Nomor 1, Desember 2018

Rusdayanti Asma; Redawati

\section{Metode Penelitian}

\subsection{Pemilihan Sampel dan Data}

Sampel penelitian ini dipilih dengan metode purposive sampling terhadap perusahaan go publik yang terdaftar pada Bursa Efek Indonesia (BEI) tahun 2015, kecuali untuk perusahaan perbankan dan lembaga keuangan lainnya serta perusahaan yang dimiliki oleh Pemerintah Republik Indonesia. Alasan ini mengacu pada pernyataan Jensen dan Meckling (1976) bahwa industri-industri dengan regulasi yang tinggi seperti public utilities atau bank akan mempunyai debt equity ratio yang tinggi yang se-ekuivalen dengan tingginya risiko yang melekat pada industri yang bersangkutan daripada non regulated firms. Kriteria lainnya adalah laporan keuangan perusahaan sampel tidak menunjukkan adanya saldo total ekuitas yang negatif dan atau mengalami kerugian selama tahun periode yang diamati. Karena saldo ekuitas dan laba yang negatif sebagai penyebut menjadi tidak bermakna (Subekti, 2000).

\subsection{Variabel Penelitian}

Berkaitan dengan metode analisis data yang digunakan dalam penelitian ini yaitu SEMPLS, maka penelitian ini menggunakan istilah untuk variabel- variabelnya sesuai dengan metode tersebut. Dalam penelitian ini variabel eksogen/prediktor terdiri dari Mekanisme GCG (X1), Kebijakan Investasi (X2) dan Kebijakan Dividen (X3), sedangkan untuk variabel endogen/kriterionnya ialah Kebijakan Pendanaan (Z) dan nilai perusahaan (Y).

\subsection{Metode Analisis}

Analisis multivariate eksploratoris digunakan dalam penelitian ini karena belum ada atau masih terbatasnya teori yang berkaitan dengan Mekanisme GCG, Kebijakan Investasi, Kebijakan Dividen dan Kebijakan Pendanaan maupun nilai perusahaan, meskipun untuk Kebijakan Pendanaan dan Kebijakan Dividen sudah memiliki teori yang menjelaskan hubungannya dengan nilai perusahaan. Adapun metode analisisnya penelitian ini menggunakan Partial Least Squares SEM (SEM-PLS). Secara konseptual, SEM-PLS mirip dengan analisis regresi ordinary least square (OLS) karena bertujuan memaksimalkan variansi variabel dependen yang dapat terjelaskan dalam model. Dengan kata lain, tujuannya adalah memaksimalkan nilai R-Squared dan meminimalkan residual atau kesalahan (error) prediksi. Selain itu tujuan yang hampir sama dengan regresi OLS tersebut, tujuan lain SEM-PLS adalah mengevaluasi kualitas data berdasarkan model pengukuran. Oleh karena itu, SEM-PLS dapat dipandang sebagai gabungan regresi dan analisis faktor. SEM-PLS tetap dapat menghasilkan estimasi meskipun untuk ukuran sampel kecil dan penyimpangan dari asumsi normalitas multivariat. Ilustrasi pemodelan persamaan pengukuran dan struktural serta notasi PLS (di adaptasi dari I Gede \& Sumartajaya 2008) pada Gambar 1 di bawah ini. 
INOBIS: Jurnal Inovasi Bisnis dan Manajemen Indonesia

Volume 2, Nomor 1, Desember 2018

Rusdayanti Asma; Redawati

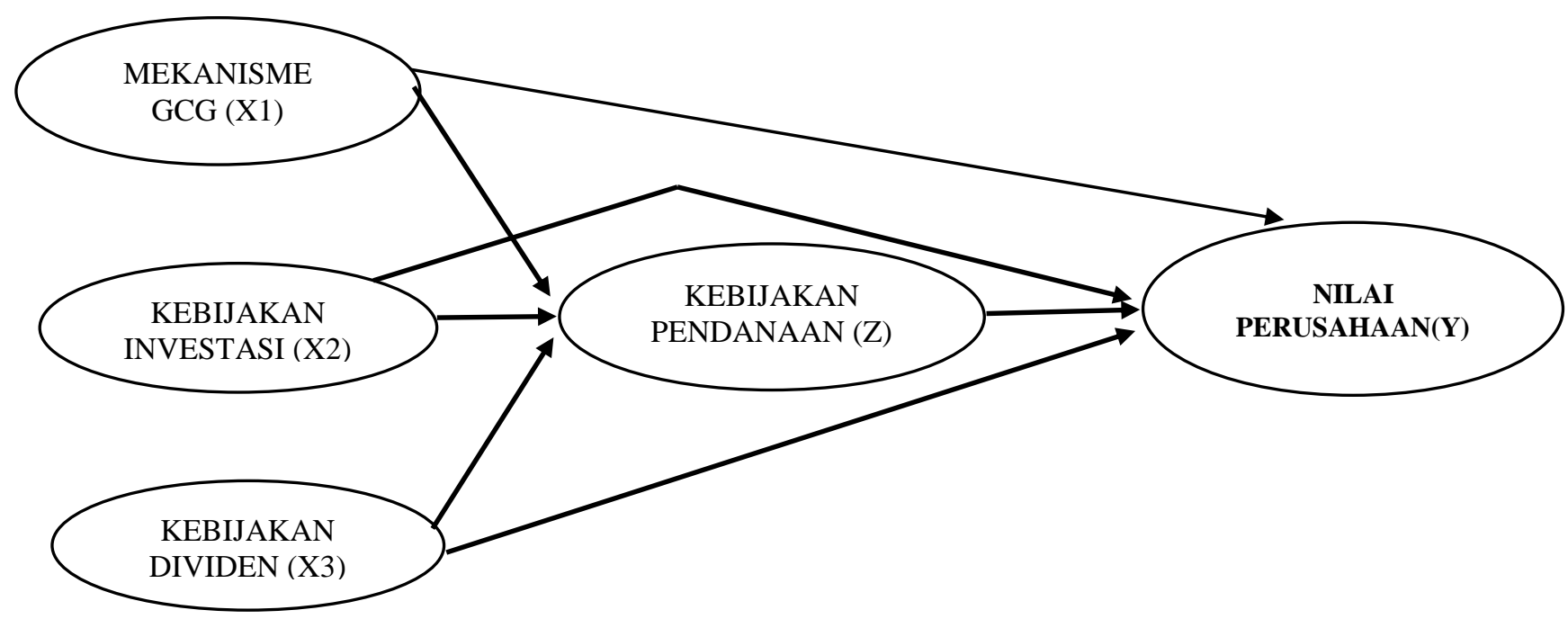

Gambar 1

Hubungan Antar Variabel dalam Model PLS

\section{Hasil dan Pembahasan}

\subsection{Model Fit}

Berdasarkan hasil pengujian dengan WarpPLS 5.0, maka dapat diperoleh perhitungan model fit yang gunanya adalah untuk mengevaluasi apakah model fit sesuai atau didukung oleh data sebagai berikut:

Tabel 1

Analisis Model Fit

\begin{tabular}{lclcc}
\hline & Nilai & Syarat & Sig. & Kesimpulan \\
\hline Average path coefficient (APC) & 0,136 & $<0,05$ & 0,006 & Signifikan \\
Average R-squared (ARS) & 0,086 & $<0,05$ & 0,039 & Signifikan \\
Average block VIF (AVIF) & 1,027 & $<5$ & - & Tidak ada \\
& & & & Multikolinearitas \\
\hline
\end{tabular}

Sumber: Hasil WrapPLS 5.0 (data diolah 2017)

Hasil output menunjukkan APC sebesar 0,136 dan ARS sebesar 0,086 serta kriteria goodness of fit model telah terpenuhi yaitu signifikan (nilai p memenuhi syarat $<0,05$ ). Nilai AVIF sebesar 1,027 juga telah memenuhi kriteria yaitu kurang dari 5 yang menunjukkan tidak adanya multikolinearitas dalam model.

\subsection{Evaluasi Model Pengukuran (Outer Model)}

Pada model pengukuran dilakukan hubungan antara indikator dan konstruk dengan menilai validitas dan reliabilitas. Ringkasan hasil output combined loading and cross-loading pada program WarPLS 5.0 yang digunakan dalam penelitian ini untuk indikator-indikator setiap variabel yang diteliti disajikan tabel 2 berikut ini. 
INOBIS: Jurnal Inovasi Bisnis dan Manajemen Indonesia

Volume 2, Nomor 1, Desember 2018

Rusdayanti Asma; Redawati

Tabel 2

Output Combined Loadings and Cross-Loadings \& Indicator Weight

\begin{tabular}{|c|c|c|c|c|c|c|c|}
\hline Varibel & $\begin{array}{c}\text { Indikato } \\
\mathbf{r}\end{array}$ & Loadings & P value & Keterangan & $\underset{t}{\text { Weigh }}$ & VIF & $\begin{array}{l}\text { Uji } \\
\text { Sig. }\end{array}$ \\
\hline \multirow{4}{*}{$\operatorname{GCG}\left(\mathrm{X}_{1}\right)$} & $\mathrm{X}_{1.1}$ & 0,849 & $<0,001$ & Valid & 0,515 & 1,420 & Sig. \\
\hline & $\mathrm{X}_{1.2}$ & 0,837 & $<0,001$ & Valid & 0,507 & 1,423 & Sig. \\
\hline & $\mathrm{X}_{1.3}$ & $-0,136$ & 0,012 & Valid & $-0,082$ & 1,105 & Sig. \\
\hline & $\mathrm{X}_{1.4}$ & 0,457 & $<0,001$ & Valid & 0,277 & 1,138 & Sig. \\
\hline Kebijakan & $\mathrm{X}_{2.1}$ & 0,762 & $<0,001$ & Valid & 0,704 & 1,009 & Sig. \\
\hline \multirow{3}{*}{$\begin{array}{l}\text { Investasi } \\
\quad\left(\mathrm{X}_{2}\right)\end{array}$} & $\mathrm{X}_{2.2}$ & $-0,285$ & $<0,001$ & Valid & $-0,257$ & 1,006 & Sig. \\
\hline & $\mathrm{X}_{2.3}$ & 0,443 & $<0,001$ & Valid & 0,405 & 1,004 & Sig. \\
\hline & $\mathrm{X}_{2.4}$ & 0,475 & $<0,001$ & Valid & 0,443 & 1,008 & Sig. \\
\hline \multirow{2}{*}{$\begin{array}{c}\text { Kebijakan } \\
\text { Dividen } \\
\left(\mathrm{X}_{3}\right)\end{array}$} & $\mathrm{X}_{3.1}$ & 0,789 & $<0,001$ & Valid & 0,633 & 1,165 & Sig. \\
\hline & $\mathrm{X}_{3.2}$ & 0,789 & $<0,001$ & Valid & 0,633 & 1,165 & Sig. \\
\hline \multirow{2}{*}{$\begin{array}{c}\text { Kebijakan } \\
\text { Pendanaa } \\
\mathrm{n}\left(\mathrm{Z}_{1}\right)\end{array}$} & $\mathrm{Y}_{1.1}$ & 0,784 & $<0,001$ & Valid & 0,638 & 1,055 & Sig. \\
\hline & $\mathrm{Y}_{1.2}$ & 0,784 & $<0,001$ & Valid & 0,638 & 1,055 & Sig. \\
\hline \multirow{2}{*}{$\begin{array}{c}\text { Nilai } \\
\text { Perusahaa } \\
\mathrm{n}\left(\mathrm{Y}_{2}\right)\end{array}$} & $\mathrm{Y}_{1}$ & 0,714 & $<0,001$ & Valid & 0,700 & 1,000 & Sig. \\
\hline & $\mathrm{Y}_{2}$ & 0,714 & $<0,001$ & Valid & 0,700 & 1,000 & Sig. \\
\hline
\end{tabular}

Sumber: Hasil WrapPLS 5.0 (data diolah 2017)

Hasil indicator weight indikator-indikator pengukur dari variabel GCG, Kebijakan Investasi, Kebijakan Dividen, Kebijakan Pendanaan dan Nilai Perusahaan disajikan dalam Tabel 2. Berdasarkan Tabel 2, dapat dideskripsikan bahwa hasil indicator weight variabel GCG, Kebijakan Investasi, Kebijakan Dividen, Kebijakan Pendanaan dan Nilai Perusahaan indikator pengukurnya menunjukkan nilai yang signifikan. Hal ini berarti bahwa indicator-indikator tersebut adalah signifikan mengukur variabel yang digunakan dalam Penelitian. Kemudian dilihat dari nilai VIF untuk Indikator-indikator yang digunakan dalam penelitian nilainya yang kurang dari 2,5, maka disimpulkan tidak ada multikolinearitas.

\subsection{Evaluasi Model Struktural (Inner Model)}

Evaluasi model struktural berkaitan pada evaluasi hubungan antara variabel laten dengan menilai koefisien determinasi, reliabilitas instrumen, validitas diskriminan, full colliniearity test, dan validitas prediktif (predictive validity). Pada tabel 3 menyajikan berbagai hasil yang diperlukan untuk mengevaluasi model struktural (inner model). 
INOBIS: Jurnal Inovasi Bisnis dan Manajemen Indonesia

Volume 2, Nomor 1, Desember 2018

Rusdayanti Asma; Redawati

Tabel 3

Hasil Pengujian Model Struktural (Inner Model)

\begin{tabular}{|c|c|c|c|c|c|}
\hline & GCG & KINV & KDIV & KDN & NP \\
\hline R-Squared & - & - & - & 0,015 & 0,156 \\
\hline Adj. R-Squared & - & - & - & 0,004 & 0,143 \\
\hline $\begin{array}{l}\text { Composite } \\
\text { Reliab. }\end{array}$ & 0,632 & 0,400 & 0,768 & 0,761 & 0,675 \\
\hline $\begin{array}{c}\text { Cronbach's } \\
\text { alpha }\end{array}$ & 0,419 & 0,040 & 0,395 & 0,373 & 0,038 \\
\hline Avg. var. extract & 0,412 & 0,271 & 0,623 & 0,614 & 0,510 \\
\hline Full Collin. VIF & 1,038 & 1,017 & 1,063 & 1,023 & 1,044 \\
\hline Q-Squared & - & - & - & 0,018 & 0,147 \\
\hline
\end{tabular}

Sumber: Hasil WrapPLS 5.0 (data diolah 2017)

Koefisien determinasi menggunakan R (squared) yang menunjukkan persentase variansi konstruk endogen/kriterion dapat dijelaskan oleh konstruk yang dihipotesiskan memengaruhinya (eksogen/prediktor). Nilai R (squared) 0,75; 0,50; dan 0,25 untuk setiap variabel laten endogen dalam model struktural dapat diinterpretasikan sebagai substansial, moderat, dan lemah. R (squared) konstruk kinerja perusahaan sebesar 0,015 menunjukkan bahwa variansi kebijakan pendanaan dapat dijelaskan sebesar $1,5 \%$ oleh variansi GCG, kebijakan investasi dan kebijakan dividen. Hal ini menunjukkan lemahnya kemampuan GCG, kebijakan investasi dan kebijakan dividen dalam menjelaskan variansi kebijakan pendanaan. $\mathrm{R}$ (squared) konstruk nilai perusahaan sebesar 0,156 menunjukkan bahwa variansi nilai perusahaan dapat dijelaskan sebesar 15,6\% oleh variansi GCG, kebijakan investasi, kebijakan dividen dan kebijakan pendanaan.

\subsection{Hasil Pengujian Hipotesis} berikut.

Secara lengkap hasil pengujian hipotesis pengaruh langsung dapat dilihat pada Tabel 4,

Tabel 4

Ringkasan Hasil Pengujian Hipotesis Pengaruh Langsung

\begin{tabular}{llccc}
\hline \multicolumn{1}{c}{ Variabel Independen } & \multicolumn{1}{c}{ Variabel Dependen } & $\begin{array}{c}\text { Path } \\
\text { Coef. }\end{array}$ & P-Value & Hasil \\
\hline Mekanisme GCG $\left(\mathrm{X}_{1}\right)$ & Kebijakan Pendanaan $\left(\mathrm{Y}_{1}\right)$ & $-0,060$ & 0,162 & $\begin{array}{c}\text { Tidak } \\
\text { Signifikan }\end{array}$ \\
\hline Mekanisme GCG $\left(\mathrm{X}_{1}\right)$ & Nilai Perusahaan $\left(\mathrm{Y}_{2}\right)$ & 0,043 & 0,239 & $\begin{array}{c}\text { Tidak } \\
\text { Signifikan }\end{array}$ \\
\hline Kebijakan Investasi $\left(\mathrm{X}_{2}\right)$ & Kebijakan Pendanaan $\left(\mathrm{Y}_{1}\right)$ & 0,096 & 0,056 & Signifikan \\
\hline Kebijakan Investasi $\left(\mathrm{X}_{2}\right)$ & Nilai Perusahaan $\left(\mathrm{Y}_{2}\right)$ & $-0,295$ & $<0,01$ & Signifikan \\
\hline Kebijakan Dividen $\left(\mathrm{X}_{3}\right)$ & Kebijakan Pendanaan $\left(\mathrm{Y}_{1}\right)$ & $-0,037$ & 0,269 & $\begin{array}{c}\text { Tidak } \\
\text { Signifikan }\end{array}$ \\
\hline Kebijakan Dividen $\left(\mathrm{X}_{3}\right)$ & Nilai Perusahaan $\left(\mathrm{Y}_{2}\right)$ & 0,216 & $<0,01$ & Signifikan \\
\hline Kebijakan Pendanaan $\left(\mathrm{Y}_{1}\right)$ & Nilai Perusahaan $\left(\mathrm{Y}_{2}\right)$ & 0,206 & $<0,01$ & Signifikan \\
\hline Sumber: Hasil WrapPLS 5.0 (data diolah 2017) & & &
\end{tabular}


INOBIS: Jurnal Inovasi Bisnis dan Manajemen Indonesia

Volume 2, Nomor 1, Desember 2018

Rusdayanti Asma; Redawati

Selanjutnya hasil analisis jalur secara lengkap disajikan pula dalam bentuk gambar seperti yang tampak pada Gambar 2 berikut,

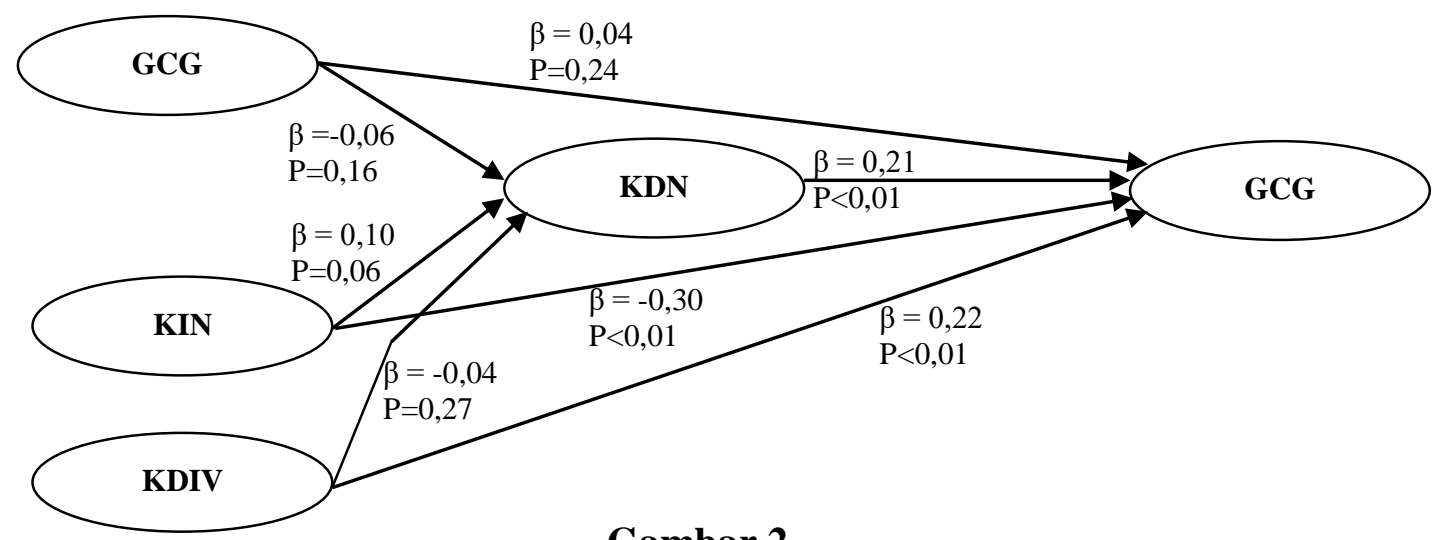

Gambar 2

Hasil Analisis Jalur-PLS

Sesuai dengan Tabel 4 dan Gambar 2, dapat dijelaskan hasil pengujian hipotesis pengaruh langsung antar variabel sebagai berikut:

1. Hipotesis $1\left(\mathrm{H}_{1}\right)$ menyatakan bahwa Mekanisme $\mathrm{GCG}\left(\mathrm{X}_{1}\right)$ berpengaruh terhadap kebijakan pendanaan $\left(\mathrm{Z}_{1}\right)$. Hasil pengujian menunjukkan path coefficients atau koefisien jalur sebesar $-0.06(\mathrm{p}=0,162)$. Hal ini berarti $\mathrm{H}_{1}$ ditolak atau $\mathrm{GCG}\left(\mathrm{X}_{1}\right)$ tidak berpengaruh terhadap kebijakan pendanaan $\left(\mathrm{Y}_{1}\right)$.

2. Hipotesis $2\left(\mathrm{H}_{2}\right)$ menyatakan bahwa Mekanisme GCG $\left(\mathrm{X}_{1}\right)$ berpengaruh terhadap nilai perusahaan $\left(\mathrm{Y}_{1}\right)$. Hasil pengujian menunjukkan path coefficients atau koefisien jalur sebesar 0,043 ( $\mathrm{p}=0,239)$. Hal ini berarti $\mathrm{H}_{2}$ ditolak atau GCG $\left(\mathrm{X}_{1}\right)$ tidak berpengaruh signifikan terhadap nilai perusahaan $\left(\mathrm{Y}_{1}\right)$.

3. Hipotesis $3\left(\mathrm{H}_{3}\right)$ menyatakan bahwa kebijakan investasi $\left(\mathrm{X}_{2}\right)$ berpengaruh terhadap kebijakan pendanaan $\left(\mathrm{Z}_{1}\right)$. Hasil pengujian menunjukkan path coefficients atau koefisien jalur sebesar 0,096 $(\mathrm{p}=0,056)$. Hal ini berarti $\mathrm{H}_{3}$ diterima atau kebijakan investasi $\left(\mathrm{X}_{2}\right)$ berpengaruh terhadap kebijakan pendanaan $\left(Z_{1}\right)$. Nilai koefisien jalur sebesar 0,096 menunjukkan bahwa kebijakan investasi $\left(\mathrm{X}_{2}\right)$ berpengaruh positif signifikan terhadap kebijakan pendanaan $\left(\mathrm{Z}_{1}\right)$.

4. Hipotesis $4\left(\mathrm{H}_{4}\right)$ menyatakan bahwa kebijakan investasi $\left(\mathrm{X}_{2}\right)$ berpengaruh terhadap nilai perusahaan $\left(\mathrm{Y}_{1}\right)$. Hasil pengujian menunjukkan path coefficients atau koefisien jalur sebesar -0,295 $(\mathrm{p}<0,01)$. Hal ini berarti $\mathrm{H}_{4}$ diterima atau kebijakan investasi $\left(\mathrm{X}_{2}\right)$ berpengaruh terhadap nilai perusahaan $\left(\mathrm{Y}_{1}\right)$. Nilai koefisien jalur sebesar $-0,295$ menunjukkan bahwa kebijakan investasi $\left(\mathrm{X}_{2}\right)$ berpengaruh negatif terhadap nilai perusahaan $\left(\mathrm{Y}_{1}\right)$.

5. Hipotesis $5\left(\mathrm{H}_{5}\right)$ menyatakan bahwa kebijakan dividen $\left(\mathrm{X}_{3}\right)$ berpengaruh terhadap kebijakan pendanaan $\left(\mathrm{Z}_{1}\right)$. Hasil pengujian menunjukkan path coefficients atau koefisien jalur sebesar $-0,037(\mathrm{p}=269)$. Hal ini berarti $\mathrm{H}_{5}$ ditolak atau kebijakan dividen $\left(\mathrm{X}_{3}\right)$ tidak berpengaruh terhadap kebijakan pendanaan $\left(Z_{1}\right)$.

6. Hipotesis $6\left(\mathrm{H}_{6}\right)$ menyatakan bahwa kebijakan dividen $\left(\mathrm{X}_{3}\right)$ berpengaruh terhadap nilai perusahaan $\left(\mathrm{Y}_{1}\right)$. Hasil pengujian menunjukkan path coefficients atau koefisien jalur sebesar 0,216 $(\mathrm{p}<0,01)$. Hal ini berarti $\mathrm{H}_{6}$ diterima atau kebijakan dividen $\left(\mathrm{X}_{3}\right)$ 
INOBIS: Jurnal Inovasi Bisnis dan Manajemen Indonesia

Volume 2, Nomor 1, Desember 2018

Rusdayanti Asma; Redawati

berpengaruh terhadap nilai perusahaan $\left(\mathrm{Y}_{1}\right)$. Nilai koefisien jalur sebesar 0,216 menunjukkan bahwa kebijakan dividen $\left(\mathrm{X}_{3}\right)$ berpengaruh positif terhadap nilai perusahaan $\left(\mathrm{Y}_{1}\right)$.

7. Hipotesis $7\left(\mathrm{H}_{7}\right)$ menyatakan bahwa kebijakan pendanaan $\left(\mathrm{Z}_{1}\right)$ berpengaruh terhadap nilai perusahaan $\left(\mathrm{Y}_{1}\right)$. Hasil pengujian menunjukkan path coefficients atau koefisien jalur sebesar $0,206(\mathrm{p}<0,01)$. Hal ini berarti $\mathrm{H}_{7}$ diterima atau kebijakan pendanaan $\left(\mathrm{Z}_{1}\right)$ berpengaruh terhadap nilai perusahaan $\left(\mathrm{Y}_{1}\right)$. Nilai koefisien jalur sebesar 0,206 menunjukkan bahwa kebijakan pendanaan $\left(Z_{1}\right)$ berpengaruh positif terhadap nilai perusahaan $\left(\mathrm{Y}_{1}\right)$.

Selanjutnya hasil pengujian pengaruh tidak langsung sebagai ikutan dari pengujian pengaruh langsung antar variabel yang diteliti. Pengujian tersebut terkait dengan peran Kebijakan Pendanaan $(Z)$ sebagai variabel perantara (intervening) dari pengaruh langsung antar variabel, yaitu pengaruh mekanisme GCG $\left(\mathrm{X}_{1}\right)$, Kebijakan Investasi $\left(\mathrm{X}_{2}\right)$ dan Kebijakan Dividen (X3) terhadap nilai perusahaan (Y). Secara ringkas, hasil pengujian mediasi dapat digambarkan sebagai berikut:

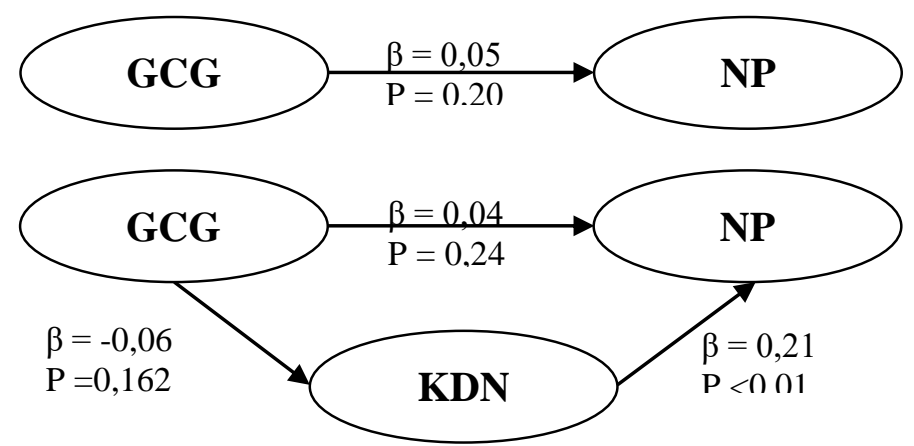

Gambar 3

Hasil Pengujian Model Mediasi Hipotesis 8

Hipotesis $8\left(\mathrm{H}_{8}\right)$ menyatakan bahwa GCG $\left(\mathrm{X}_{1}\right)$ berpengaruh terhadap nilai perusahaan $\left(\mathrm{Y}_{1}\right)$ melalui kebijakan pendanaan $\left(\mathrm{Z}_{1}\right)$. Pada Gambar 5.2, dapat dilihat bahwa mekanisme GCG $\left(\mathrm{X}_{1}\right)$ tidak berpengaruh terhadap kebijakan pendanaan $\left(\mathrm{Y}_{1}\right)$, sehingga kebijakan pendanaan $\left(\mathrm{Y}_{1}\right)$ tidak mampu memediasi pengaruh GCG (X1) terhadap Nilai Perusahaan (Y)

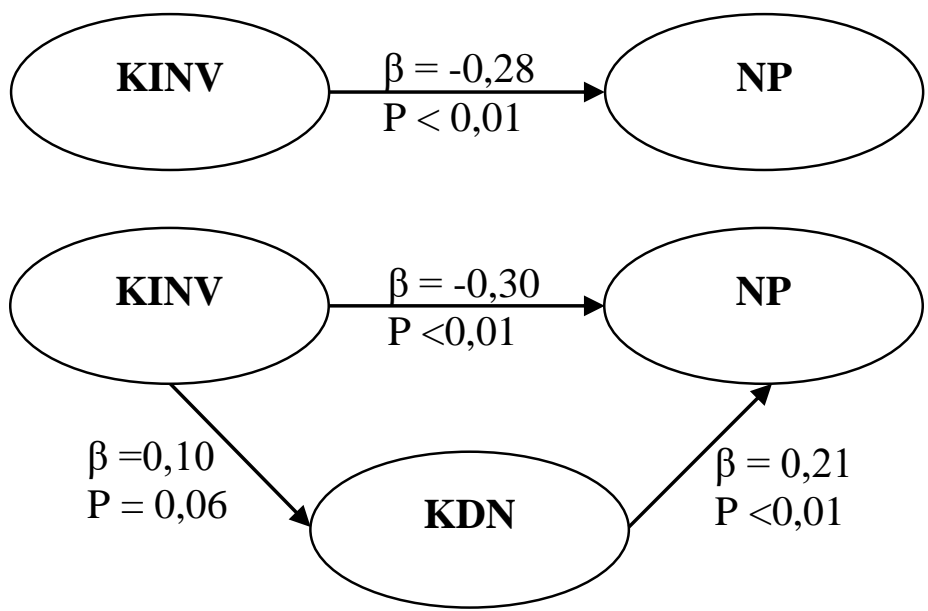

Gambar 4

Hasil Pengujian Model Mediasi Hipotesis 9 
INOBIS: Jurnal Inovasi Bisnis dan Manajemen Indonesia

Volume 2, Nomor 1, Desember 2018

Rusdayanti Asma; Redawati

Hipotesis $9\left(\mathrm{H}_{9}\right)$ menyatakan bahwa kebijakan investasi $\left(\mathrm{X}_{2}\right)$ berpengaruh terhadap nilai perusahaan $\left(\mathrm{Y}_{1}\right)$ melalui kebijakan pendanaan $\left(\mathrm{Z}_{1}\right)$. Hasil estimasi menunjukkan bahwa koefisien direct effect kebijakan investasi $\left(\mathrm{X}_{2}\right)$ terhadap nilai perusahaan $\left(\mathrm{Y}_{1}\right)$ adalah sebesar 0,28 dan signifikan ( $\mathrm{p}<0.01$ ). Pada Gambar 4 , hasil estimasi pada model indirect effect kebijakan investasi $\left(\mathrm{X}_{2}\right)$ terhadap nilai perusahaan $\left(\mathrm{Y}_{2}\right)$ melalui kebijakan pendanaan $\left(\mathrm{Y}_{1}\right)$ menunjukkan nilai turun dan tetap signifikan. Sehingga dapat disimpulkan bahwa kebijakan investasi $\left(\mathrm{X}_{2}\right)$ berpengaruh terhadap nilai perusahaan $\left(\mathrm{Y}_{2}\right)$ melalui kebijakan pendanaan $\left(\mathrm{Y}_{1}\right)$ Bentuk mediasi adalah mediasi parsial (partial mediating).

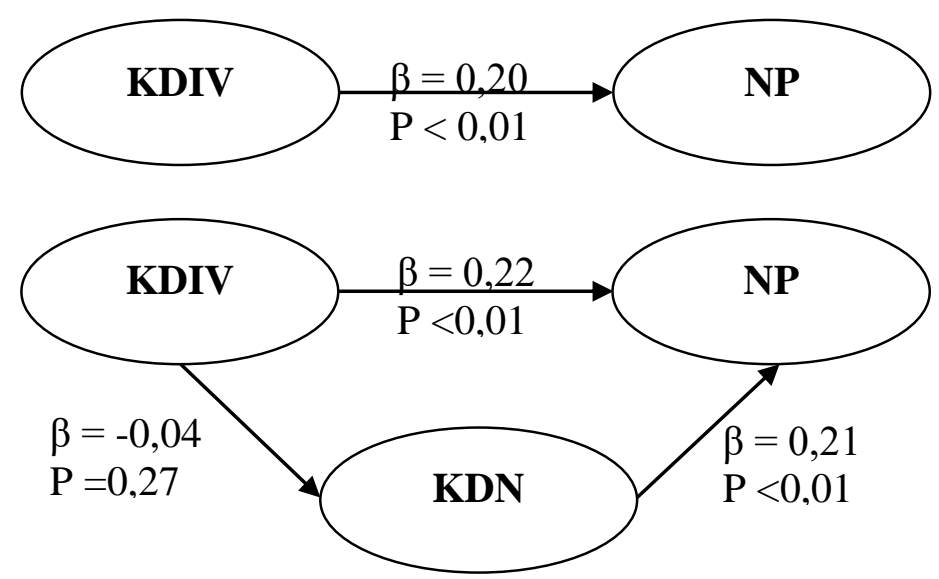

Gambar 5

Hasil Pengujian Model Mediasi Hipotesis 10

Hipotesis $10\left(\mathrm{H}_{10}\right)$ menyatakan bahwa kebijakan dividen $\left(\mathrm{X}_{3}\right)$ berpengaruh terhadap nilai perusahaan $\left(\mathrm{Y}_{1}\right)$ melalui kebijakan pendanaan $\left(\mathrm{Z}_{1}\right)$. Pada Gambar 5, dapat dilihat bahwa kebijakan dividen $\left(\mathrm{X}_{3}\right)$ tidak berpengaruh terhadap kebijakan pendanaan $\left(\mathrm{Z}_{1}\right)$, sehingga kebijakan pendanaan $\left(\mathrm{Y}_{1}\right)$ tidak mampu menjadi variabel mediasi.

\subsection{Pembahasan}

Penelitian ini bertujuan untuk mengetahui pengaruh Mekanisme GCG, Kebijakan Investasi dan Kebijakan Dividen terhadap nilai perusahaan dengan Kebijakan pendanaan sebagai variabel mediasi. Berdasarkan hasil penelitian diketahui bahwa mekanisme GCG tidak berpengaruh terhadap kebijakan pendanaan. Hasil tersebut menunjukkan bahwa mekanisme GCG belum secara optimal dapat mempengaruhi keputusan penggunaan kewajiban untuk digunakan dalam penambahan modal (keputusan pendanaan). Alasan yang mendasari hasil uji penelitian ini adalah pelaksanaan mekanisme GCG diduga hanya sebagai formalitas belaka, sementara pemegang saham mayoritas (blockholders) masih memegang peranan penting, sehingga tidak ada pengaruh antara mekanisme GCG terhadap Kebijakan Pendanaan. Hasil Penelitian juga menemukan bahwa mekanisme GCG tidak berpengaruh terhadap Nilai Perusahaan. Mekanisme GCG dalam pelaksanaannya masih dianggap sebagai kewajiban yang harus dilaksanakan oleh perusahaan, bukan sebagai budaya. Sehingga investor dan calon investor tidak memberikan respon terhadap informasi mengenai mekanisme GCG karena menganggap mekanisme GCG hanyalah formalitas yang wajib dijalankan oleh perusahaan.

Penelitian ini juga memperlihatkan hasil bahwa Keputusan Investasi berpengaruh positif dan Signifikan terhadap Keputusan Pendanaan. Pada dasarnya, Keputusan investasi merupakan 
INOBIS: Jurnal Inovasi Bisnis dan Manajemen Indonesia

Volume 2, Nomor 1, Desember 2018

Rusdayanti Asma; Redawati

hubungan antara pengeluaran saat ini maupun dimasa yang akan datang dengan nilai atau retrun serta prospek sebagai hasil dari keputusan investasi untuk menciptakan nilai perusahaan. Secara umum keputusan investasi menggambarkan tentang peluang investasi bagi perusahaan, namun sangat tergantung pada pilihan pengeluaran perusahaan untuk kepentingan dimasa yang akan datang. Semakin banyak peluang investasi maka semakin besar pula dana yang dibutuhkan oleh perusahaan untuk mendanai setiap investasi. Jika perusahaan tidak mempunyai dana internal maka perusahaan akan menggunakan utang untuk membiayai investasi tersebut. Penelitian ini juga menemukan bahwa Keputusan Investasi berpengaruh negatif signifikan terhadap Nilai Perusahaan. Hal ini memperlihatkan bahwa investor memperkirakan bahwa investasi yang dilakukan oleh perusahaan diperkirakan akan menurun dimasa yang akan datang. Pemikiran investor ini didukung dengan adanya fenomena perlambatan ekonomi global yang juga berdampak pada penurunan nilai investasi perusahaan yang secara tidak langsung juga akan berdampak pada penurunan nilai perusahaan.

Penelitian ini juga menemukan bahwa Kebijakan Dividen tidak berpengaruh terhadap Kebijakan Pendanaan. Teori yang relevan untuk menjelaskan temuan ini adalah Pecking Order Theory. Secara ringkas teori tersebut menyatakan bahwa perusahaan akan lebih menggunakan dana internalnya terlebih dahulu untuk membiayai investasi sebelum menggunakan pembiayaan eksternal melalui hutang. Berdasarkan hasil Penelitian diketahui bahwa Kebijakan Dividen berpengaruh positif terhadap nilai Perusahaan. Pada dasarnya dividen digunakan untuk mengurangi asimetri informasi serta sebagai isyarat bahwa perusahaan mempunyai prospek baik yakni dengan membagikan dividen kepada pemegang saham. Kebijakan dividen merupakan keputusan yang sangat penting bagi perusahaan untuk memberikan sinyal kepada pihak luar tentang prospek perusahaan. Pembayaran dividen menunjukkan prospek perusahaan semakin bagus sehingga investor akan tertarik untuk membeli saham dan nilai perusahaan akan meningkat. Keuntungan yang diperoleh perusahaan dapat menentukan kesejahteraan pemegang saham. Perusahaan dianggap baik nilainya ketika investor melakukan investasi dan mendapat keuntungan dari dana yang diinvestasikannya kedalam perusahaan.

Hasil penelitian juga memperlihatkan bahwa Kebijakan pendanaan yang terkait pada keputusan sumber dana yang digunakan oleh perusahaan dalam memenuhi dana operasionalnya berpengaruh positif terhadap nilai perusahaan. Hasil penelitian ini sesuai dengan konsep teori sinyal bahwa perusahaan yang meningkatkan utang bisa dipandang sebagai perusahaan yang yakin dengan prospek perusahaan di masa mendatang. Investor diharapkan akan menangkap signal tersebut, signal bahwa perusahaan mempunyai prospek yang baik. Dengan demikian utang merupakan tanda atau signal positif.

Hasil penelitian ini juga menemukan bahwa kebijakan pendanaan tidak mampu memediasi hubungan antara mekanisme GCG dan Kebijakan Dividen terhadap Nilai Perusahaan, tetapi mampu mediasi hubungan antara Kebijakan Investasi terhadap Nilai Perusahaan.

\section{Simpulan}

Berdasarkan hasil pengujian diketahui bahwa hasil pengujian pengaruh langsung menunjukkan bahwa Kebijakan investasi berpengaruh terhadap Kebijakan Pendanaan, sedangkan Mekanisme GCG dan Kebijakan dividen tidak berpengaruh terhadap Kebijakan Pendanaan. Hasil Pengujian juga menunjukkan bahwa Kebijakan investasi, Kebijakan dividen dan Kebijakan Pendanaan berpengaruh terhadap nilai Perusahaan sedangkan Mekanisme GCG tidak berpengaruh terhadap nilai Perusahaan. Hasil pengujian pengaruh tidak langsung menunjukkan bahwa kebijakan pendanaan mampu memediasi hubungan antara Kebijakan 
INOBIS: Jurnal Inovasi Bisnis dan Manajemen Indonesia

Volume 2, Nomor 1, Desember 2018

Rusdayanti Asma; Redawati

Investasi dengan nilai perusahaan, tetapi tidak mampu memediasi hubungan antara Mekanisme GCG dan kebijakan dividen dengan nilai Perusahaan.

\section{Referensi}

Agrawal and N. Jayaraman, 1994, The Dividend Policies of All-Equity Firm: A Direct Test of The Free Cash Flow Theory, Managerial and Decision Economics; 15, pp. 139-148

Ammann, M. 2010. Corporate Governance and Firm Value: International Evidence.

Atacik \& Jarvis. 2006. Better Corporate Governance: More Value for Everyone, Business \& Development Discussion Papers, Paper No.02.

Brigham, E.F., dan Houston, J. 2006. Manajemen Keuangan, Buku IL Edisi Kedelapan. lakarta: Erlangga

Chung, K. H., \& Charoenwong, C. 2013. Investment options, Assets in place, and the Risk of Stocks. Financial Management, 20(3), 21-33.

Fallatah, Y \& Dickins, D. 2012. Corporate governance and firm performance and value in Saudi Arabia, African Journal of Business Management Vol.6 (36).

Fama, E.F and French, K.R. 1998. Taxes, Financing Decision, and Firm Value, The Journal of Finance. Vol. LIII No. 3 June, pp. 819-843

Garay, U \& Gonzales, M. 2008. Corporate Governance and Firm Value: The Case of Venezuela. Corporate Governance International Review Vol. 16 No. 3 pp. 194-209 2008

Gupta, P. P. 2009. Corporate Governance and Firm Value: Evidencefrom Canandian Capital Markets, Corporate Ownership \& Control/Volume 6, Issue 3, Spring 2009

Hartono, U. 2013, Firm Characteristic, Corporate Governance and Firm Value, International Journal of Business and Behavioral Sciences Vol. No.8: August 2013

Hasnawati, S. 2005. Implikasi Keputusan Investasi , Pendanaan, dan Dividen Terhadap Nilai Perusahaan Publik di Bursa Efek Jakarta, Usahawan: No. 09/Th XXXIX, September 2005.

Husnan, S., \& Pudjiastuti, E. 2006. Dasar Manajemen Keuangan Edisi 5. Yogyakarta: UPP STIM YKPN.

Jensen, M.C., and W. H. Meckling. 1976. Theory of The Firm: Manajerial Behaviour, Agency Cost, and Ownership Structure. Journal of Financial and Economics, 3, 305-360.

Kallapur,S., Lafayette,W., \& Trombley, M. A. 2001. The Investment Opportunity Set: Determinants, Consequences and Measurement. Managerial Finance, 27(3).

Myers, S. C. 1977. Determinants of Corporate. Journal of Financial Economics ,5 , 147 - 175

Nurlela, R., \& Islahuddin. 2008. Pengaruh Corporate Social Responsibility terhadap Nilai Perusahaan dengan Prosentase Kepemilikan Manajemen Sebagai Variabel Moderating. Simposium Nasional Akuntansi XI Pontianak, (2), 1-25.

Rachmawati, A dan Triatmoko H. 2007. Analisis Faktor-faktor yang Mempengaruhi Kualitas Laba dan Nilai Perusahaan. SNA X, Makasar 26-28 Juti 2007

Ratih, S. 2011. Pengaruh Good Corporate Governance terhadap Nilai Perusahaan dengan Kinerja Keuangan sebagai Variabel Intervening pada Perusahaan Peraih The Indonesia Most Trusted Company-CGPI

Rosiana, G.A.M.E., Juliarsa, G., \& Sari, M.M.R. 2013. Pengaruh Pengungkapan CSR terhadap Nilai Perusahaan dengan Profitabilitas sebagai Variabel Pemoderasi. E-Jurnal Akuntansi Universitas Udayana, 3, 723-738. 
INOBIS: Jurnal Inovasi Bisnis dan Manajemen Indonesia

Volume 2, Nomor 1, Desember 2018

Rusdayanti Asma; Redawati

Shanti dan Wulaningrum, R. 2005. Hubungan Antara Set Kesempatan Investasi dengan Kebijakan Pendanaan Dan Dividen, Serta Leverage Finansial. Jurnal Widya Manajemen \& Akuntansi, vol 5 No 1 April 2005

Siallagan, H dan Machfoedz, M. 2006. Mekanisme Corporate Governance, Kualitas Laba dan Nilai Perusahaan.Simposium Nasional Akuntansi 9, Padang.

Sumiadji. 2011. Analisis Variabel Keuangan yang Mempengaruhi Kebijakan Dividen. Jurnal Dinamika Akuntansi, 3(2), 129-138

Wahyudi, U., \& Pawestri, H. P. 2006. Implikasi Struktur Kepemilikan terhadap Nilai Perusahaan: dengan keputusan Keuangan sebagai Variabel Intervening. Simposium Nasional Akuntansi IX Padang, 23 -26. 